\title{
DÁVID JÓZSEF
}

\section{Trafikrablás a benzinkúton}

Az Országgyülés a 2012. évi CXXXIV. törvénnyel a fiatalkorúak dohányzásának visszaszorítását, valamint a dohánytermékek kiskereskedelmét kívánta törvényben szabályozni. Az első nemzeti dohányboltok Magyarországon e törvény értelmében 2013. július 1-jén nyithattak meg. A trafikokban kezdetben nem voltak megfelelö biztonsági berendezések - saját biztonsági kamera, pánikgomb -, de e hiányosságokat rövid időn belül korrigálták. A hiányosságok sajnálatos módon oda vezettek, hogy Pécs belvárosában 2013. július 17-én megtörtént az első trafikrablás.

A törvény adta lehetőségek nyomán a nagyvárosok után a kisebb városokban, településeken is egymás után nyíltak a trafikok. Csongrád megyében 2014-ben negyvennyolc rablás történt, ebből négy trafikok ellen. Csongrádon az első trafikrablás 2014. január 5-én következett be a város területén lévő Mol üzemanyagtöltő állomáson kialakított nemzeti dohánybolt ellen.

Csongrád városa a megye északi részén található, két folyó, a Tisza és a Hármas-Körös találkozásánál. Lakossága 16827 fö, zömében időskorú. Úgy is nevezhetnék a települést, hogy a nyugalom szigete. Éppen ezért öröm itt rendőrnek lenni, fenntartani a város nyugalmát. A Csongrádi Rendőrkapitányság illetékességi területén 2014-ben ötszázkilencven regisztrált büncselekményt követtek el, ebből mindössze öt esetben történt rablás. Az erőszakos vagyon elleni deliktumok minden esetben felborzolják az amúgy nyugodt alföldi város mindennapjait, de a trafikrablás különös nyugtalansággal töltötte el mind a lakosságot, mind a csongrádi zsarukat. Tudtuk, hogy az elkövetett büncselekményt a lehető legrövidebb időn belül és a lehető legeredményesebb módon kell felderítenünk, megelözendő, hogy a város területén müködő további hét trafik is érintett legyen.

\section{Az elkövetés részletei}

Átlagos ünnepi időszak utáni téli este volt addig a bejelentésig, amely arról tájékoztatott, hogy a városból kivezető út melletti Mol benzinkúton lévő nemzeti dohányboltba 19 óra 35 perc körül egy ismeretlen személy bement, 
és a napi bevételt követelte az ott tartózkodó eladótól - szándékának egy baseballütővel nyomatékot adva. Az eladó a vele szemben alkalmazott közvetlen fenyegetés hatására a napi bevételt, százhuszonnyolcezer forintot átadta az elkövetőnek.

A bejelentés után egyenruhás és civil nyomozók keresték a büncselekmény elkövetőjét.

Az adatgyüjtéssel párhuzamosan elkezdtük az egyik legfontosabb nyomkutató tevékenységet, a helyszíni szemlét, amely a bizonyítási eljárásban rendkívül fontos és nagy jelentőségủ egyedi és megismételhetetlen tevékenység. Szinte lehetetlen, hogy az elkövető ne hagyjon maga után nyomokat, ennek felkutatása és rögzítése már a szakembereken múlik. Ennek érdekében a bünügyi technikus aprólékos részletességgel átvizsgálta a trafik minden négyzetméterét. A precíz munka nyomán az elkövető lábbelijétöl származó nyomra, valamint több helyröl szagmaradványra és DNS-anyagmaradványra lelt. A helyszín sok esetben azonnali tájékoztatást adhat a felderítés vonatkozásában. Esetünkben azonban a bizonyítékok beszerzésén túlmenően az elkövető személyének felderítése tekintetében akkor nem vitt előbbre. Ezért a felderítést folytatni kellett más vonalon, a személyi bizonyítékok megközelítése felöl.

Részletesen kihallgattuk a trafikban dolgozó eladót, aki az ijedtség miatt kialakult pszichikai állapotához képest részletes személyleírást adott az elkövetőről. Elmondása alapján az elkövető kb. 170-175 cm magas, 25 és 30 év közötti, vékony testalkatú férfi volt, aki sötét kabátot viselt, a fejére pedig egy szintén sötét színű kapucnit húzott. Az arcát fehér sállal takarta el, ami fölött napszemüveget viselt, valamint kesztyüt is húzott.

A felderítést nehezítette, hogy a nemzeti dohányboltban nem volt belső, saját videokamerás biztonsági rendszer, így csak a jelen lévő eladó elmondására tudtunk támaszkodni. További nehezítő körülmény volt, hogy a benzinkúton lévő videokamerák közül csak három müködött.

\section{Az első reményt adó jel}

Tovább folytattuk az adatgyüjtést, tanúkutatást, megállapítottuk, hogy az elkövető gépkocsival érkezett a büncselekmény helyszínére, és azzal is távozott. Ezért a felderítő tevékenységet kiterjesztettük a jármüre is.

A nyomozó egyik legjobb eszköze a felderítéskor az adatgyüjtés, ez elképzelhetetlen hely- és személyismeret nélkül. Főként ha olyan kisvárosról 
van szó, mint Csongrád, ahol szinte mindenki ismer mindenkit. Gyüjtöttük az információkat, és elemeztük, értékeltük őket. Az elkövetőről készült fantomképpel jártuk a várost, és anyagi jellegü inspiráláshoz, díjkitüzéshez is folyamodtunk.

Sikerült a jármüről adatot szerezni, a szín és a típus vonatkozásában, ami egy újabb verziót jelentett a többi mellett. A helyi nyomozók már a büncselekmény elkövetése előtt felfigyeltek egy hasonló jármüre, már csak meg kellett állapítani, ki használta. Még inkább felkeltette a nyomozók gyanúját, amikor kiderült, a jármü használója részese volt egy vagyon elleni büncselekmény miatt induló büntetőeljárásnak.

Ez a személy és társasága a tanúkénti kihallgatásakor érdemben nyilatkozni nem tudott a büncselekmény elkövetéséröl, 2014. január 5-e vonatkozásában sziklaszilárd alibijük volt. Ettől függetlenül a nyomozókban gyanú vetődött fel arra vonatkozóan, hogy e korábbi bünelkövetők „füllentenek”, így valamennyiüknél házkutatást végeztek, ez egy kivételével eredménytelen volt. Az illető, B. lakásán 2014. január 7-én tartott házkutatáskor egy 60 centis baseballütőt foglaltak le, amely akár az elkövetés eszköze is lehetett.

Az előbbieken túl e személyektől személyiszag-mintát és DNS-mintát vettek. A személyiszag-minták és a szagmaradványok összehasonlító vizsgálatakor a nemzeti dohányboltban a pult elől, a földről rögzített szagmintát két szolgálati kutya is négy-négy esetben azonosnak jelezte a B.-től rögzített személyiszag-mintával.

A B.-től lefoglalt baseballütő, valamint a helyszínen rögzített két biológiaianyag-maradvány vonatkozásában azonban a DNS-vizsgálat eredménye negatív volt.

\section{A második reménysugár}

A nyomozások során fontos, hogy több verziót állítsunk fel annak érdekében, hogyha bármelyik nyomozási szál „vakvágányra” fut, ne álljunk tétlenül. Ennek érdekében folyamatos volt az információk beszerzése és azok visszaellenőrzése.

Ahogy távolodtunk a büncselekmény elkövetésének időpontjától, egyre jobban elcsüggedtünk, de ekkor jött a második reménysugár. Egy helyi informátor lényeges és hiteles felvilágosítással szolgált a büncselekmény lehetséges elkövetőjéről. Egy olyan személyröl beszélt, akire nem gondoltunk. Az informátor által megjelölt személyt, X.-et tanúként hallgattuk ki. Mint a bün- 
elkövetők többsége, tagadta, hogy bármit is tudna a büncselekményröl, ,, csak hallott róla".

A korábbi verziót sem vetettük el a büncselekmény felderítésének vonatkozásában, így poligráfos vizsgálathoz folyamodtunk.

\section{Az áttörés}

A poligráfos vizsgálatra már csak a két feltételezett elkövetőt B.-t és X.-et idéztük be. Bíztunk abban, hogy ez a vizsgálat áttörést hoz az ügyben, és a felderítésbe fektetett munka nem lesz hiábavaló. A vizsgálaton $B$. jelent meg elsőként. A rutinkérdések után következett néhány rázósabb kérdés, de sajnos a vizsgálat bebizonyította, hogy nem $B$. a mi emberünk, a töle lefoglalt baseballütő és a szagminták egyezése ellenére.

Következett X.! Mindannyian felszülten vártuk, vajon mit állapít meg a vizsgálat. A vizsgálatot vezető szakértő végül így szólt: Megvan az emberük!

A poligráfos vizsgálat után $X$. részletes és beismerő vallomást tett az ügyben. Jutalma hét év letöltendö fegyházbüntetés lett.

Összegzésül elmondhatom, hogy a reménytelennek látszó ügyekben is akadhat olyan jelentéktelennek tünő apró részinformáció, amelynek nyomán - a bizonyítás eszközeit jól alkalmazva - eljuthatunk a büncselekmény elkövetőjéhez, és bebizonyíthatjuk a bünösségét. 